BARBARA GAWDA

$\stackrel{\circ}{\text { III }}$

\title{
DYSKUSJA NAD TEZĄ O WZROŚCIE NARCYZMU WE WSPÓŁCZESNYCH SPOŁECZEŃSTWACH
}

\begin{abstract}
Barbara Gawda, Dyskusja nad tezq o wzroście narcyzmu we współczesnych społeczeństwach [Discussion of the thesis about the growth of narcissism in modern societies] edited by A. Jasielska, M. Obrębska "CZłowiek i Społeczeństwo" vol.XLV: Oblicza współczesności. Perspektywa psychologiczna [Faces of modernity. A psychological perspective], Poznań 2018, pp. 67-85, Adam Mickiewicz University. Faculty of Social Sciences Press. ISSN 0239-3271.
\end{abstract}

The article aims to discuss the thesis on 'narcissistic epidemic' that was highlighted in publications from culture and social studies. The different ways of defining of narcissism, different concepts of narcissism, psychological characteristic of people displaying narcissism, and research focused on its description will be analyzed. To illustrate the famous thesis on 'narcissistic epidemic' in the modern world the data on the prevalence of narcissistic personality disorder in many countries, including Poland, will be discussed. The documented not too high prevalence of narcissistic personality disorder in high-income countries from the world seems to be stable. It means that the thesis on increasing level of narcissism in capitalist countries was not supported by the research from psychopathology.

Barbara Gawda, Uniwersytet Marii Curie-Skłodowskiej w Lublinie, Instytut Psychologii, plac Litewski 5, 20-080 Lublin, e-mail: basia.gawda@poczta.umcs.lublin.pl 


\section{Narcyzm w różnych znaczeniach: różnorodność ujęći i modeli teoretycznych}

Pojęcie „narcyzm” zostało dość gruntownie przeanalizowane w literaturze przedmiotu, np. w pracy Anny Czarnej (2008) czy Tomasza Olchanowskiego i Jacka Sieradzana (2011). Warto podkreślić, co zresztą czynią autorzy rozpraw na temat nacyzmu, że narcyzm jest jednym z najbardziej niejasnych i kłopotliwych pojęć (Pulver, 1970, s. 319). Nie sposób zatem ująć w niniejszych rozważaniach wszystkich danych na temat narcyzmu i wszelkich jego koncepcji. Uwaga zostanie skoncentrowana na ujęciach najważniejszych, tj. psychoanalitycznych, teorii relacji z obiektem, kulturowo-społecznych i społeczno-poznawczych. Samo pojęcie wywodzi się z mitologii, nawiązuje do mitu o Narcyzie. Nabrało szczególnego znaczenia za sprawą publikacji donoszących o ,powszechnej epidemii narcyzmu” (np. Lasch, 2015; Twenge i Campbell, 2009). W opracowaniu podjęta zostanie dyskusja na temat tego, czy istotnie mamy do czynienia z „epidemią narcyzmu”, czy poglądy w związku z „epidemią” odzwierciedlają stan faktyczny, czy mają raczej charakter popularyzatorski bądź mało krytyczny. Na wstępie, w formie dość syntetycznej ze względu na fakt istnienia wielu gruntownych opracowań związanych z tym zagadnieniem, zostaną przedstawione rozważania terminologiczne i różne ujęcia teoretyczne narcyzmu, następnie zaś - krytyczne stanowisko na temat rozważań dotyczących „epidemii narcyzmu” oparte na danych z zakresu psychopatologii.

\section{Psychoanaliza}

Pojęcie narcyzmu było analizowane szczególnie na gruncie psychoanalizy. Wiązano je w tym nurcie z wieloma zjawiskami i proponowano jego różne typologie. Poczynając od klasycznych poglądów Zygmunta Freuda, wskazywana jest już wieloznaczność pojęcia „narcyzm”. Austriacki badacz wiązał narcyzm z perwersją seksualną, a także z istotą zaburzeń psychicznych (Pospiszyl, 1995). W tym drugim kontekście wyjaśniał, że człowiek rodzi się w stanie „całkowitego narcyzmu”, czyli w stanie domniemanej omnipotencji nazywanej narcyzmem pierwotnym. W ujęciu rozwojowym człowiek na początku życia kieruje wszystkie swoje potrzeby jedynie na siebie samego, po czym przechodzi przez kolejne fazy, tj. „z libidinalnej 
kateksji własnego «ego» w kateksję do obiektu pozostającego na zewnątrz" (Pospiszyl, 1995, s. 29). W sytuacji gdy obiekt zewnętrzny nie zareaguje właściwie na tę formę uczucia, siła libido wraca z powrotem do ego i pojawia się tzw. narcyzm wtórny, który stanowi zalążek psychozy, ale też wielu innych zaburzeń psychicznych (Pospiszyl, 1995, s. 32). Kolejno problematykę narcyzmu rozważali inni psychoanalitycy, jak Erich Fromm, Karen Horney, Eugene Wolf czy Alexander Lowen.

W nurcie określanym jako psychologia relacji z obiektem szczególnie rozbudował koncepcję narcyzmu Heinz Kohut, który zerwał z klasyczną psychoanalizą i zanegował model strukturalny. Wyjaśniał on zaburzenia narcystyczne osobowości, podkreślając, że wynikają z zaburzeń w strukturze self, które jest emocjonalno-motywacyjnym rdzeniem osobowości. Podstawą rozwoju spójnej struktury self są trzy osie: wielkościowości, idealizacji oraz związku z alter ego. Do zaburzeń w strukturze dochodzi, gdy rozwój self ma charakter obronny i kompensacyjny. Wtórne zakłócenia self powstają jako reakcje strukturalnie nieuszkodzonego self na trudności życia (Gościniak i Mocek, 2008). Zaburzony rozwój owocuje niewłaściwym ukształtowaniem struktury self. Wynika on najczęściej z nieprawidłowych relacji dziecka z opiekunami we wczesnym dzieciństwie. Narcyzm w ujęciu Kohuta jest dysfunkcją self, które pozostaje wyolbrzymione i nierealistyczne (Rhodewalt, 2005).

Kolejnym ważnym teoretykiem, który podejmował analizę zjawiska narcyzmu w kontekście patologii osobowości, był Otto Kernberg. Według niego self jest strukturą intrapsychiczną składającą się ze zbioru reprezentacji, które z kolei odzwierciedlają percepcję samego siebie w relacjach z innymi. W genezie zaburzenia osobowości znaczącą rolę może odgrywać negatywny afekt, który sprzyja utrzymywaniu się rozszczepienia oraz prowadzi do braku integracji struktur, formowania się dyfuzyjnej tożsamości oraz agresji. Wówczas osoba może stosować mechanizmy obronne, takie jak prymitywna idealizacja, identyfikacja projekcyjna, zaprzeczenie czy dewaluacja idealizowanego obiektu (Gawda, 2011, s. 63). Zaburzenia osobowości polegają na braku dojrzałości ego, które nie jest zdolne do różnicowania subtelnych aspektów własnego self i innych osób. Narcyzm oznacza według tej koncepcji mechanizm obronny, polegający na rozpaczliwym poszukiwaniu schronienia w tym aspekcie ja, który cenią rodzice dziecka (Lowen, 2013). Według Otto Kernberga kluczowa nie jest idealizacja self, lecz wadliwy rozwój self. Fundamentalne przyczyny rozwoju takiego self to chłód emocjonalny w relacjach rodzice-dzieci, odrzucenie dziecka, niedostępność w relacjach. Koncepcja ta opisuje mechanizm powstania 
zaburzeń osobowości jako model deficytu, którego istotą jest niewykształcenie w strukturze self odpowiednich struktur psychicznych i dojrzałych mechanizmów obronnych (Gawda, 2011, s. 64).

Oprócz wymienionych psychoanalityków i przedstawicieli teorii relacji z obiektem wielu innych badaczy zajmowało się problematyką narcyzmu (Symington, 2013, ss. 132-150). Ogólnie teorie te upatrują źródeł narcyzmu w zaburzonych relacjach pomiędzy opiekunami i dzieckiem. Wskazują na znaczenie nieprawidłowych więzi pomiędzy nimi, takich jak doświadczenia niedostępności emocjonalnej, chłodu czy nieodwzajemnionej miłości. Ujęcia psychoanalityczne i relacji z obiektem, mówiąc o narcyzmie, traktują o zaburzeniu narcystycznym względnie o patologicznym rysie osobowościowym.

Ja pisze Anna Czarna, pojęcie narcyzmu stało się szczególnie popularne w latach siedemdziesiątych ubiegłego wieku, kiedy wyszło poza granice psychologii i rozszerzyło się na socjologię, filozofię i kulturoznawstwo, za sprawą między innymi socjologa Richarda Sennetta, historyka i krytyka społecznego Christophera Lascha oraz socjologa i kulturoznawcy Anthony'ego Giddensa (Czarna, 2008, s. 5).

\section{Ujęcie kulturowo-społeczne}

W ujęciu kulturowym podkreśla się, że narcyzm jest właściwością społeczną, charakteryzującą grupy społeczne w takim sensie, iż kultura staje się przestrzenią dla realizacji partykularnych i egoistycznych celów jednostki (Szpunar, 2016). W tym kontekście narcyzm i egocentryzm/egotyzm stają się synonimami. Kultura, wartości promowane w danej kulturze sprzyjają nastawieniu egoistycznemu i kształtują popularne zachowania w relacjach społecznych w warunkach pracy i innych sytuacjach. To skutkuje wzrostem potrzeby indywidualizmu, wyjątkowości oraz dbałością o swój wizerunek społeczny i medialny. Współwystępuje na przykład z autopromocją na portalach społecznościowych (Szpunar, 2016, ss. 146-151). W tym kontekście pojawiło się pojęcie homo narcissus, które odnosi się do dwuwymiarowości człowieka. Z jednej strony osoba taka doświadcza ogromnego poczucia pustki, żyje w odosobnieniu, z drugiej - jej zupełnie odmienny wizerunek pokazywany w mediach ma pełnić funkcję ochronną przed poczuciem bezwartościowości (Szpunar, 2014). W tym miejscu nieuchronnie nasuwa się pytanie, do jakiej definicji narcyzmu nawiązują ujęcia kulturowo-społeczne. Czy odnoszą się do narcyzmu jako cechy osobowości czy do postawy społecznej, czy może do zaburzenia osobowości (niektórzy wskazują, że chodzi 
o postawę, np. Olchanowski i Sieradzan, 2011, s. 7)? Ponadto czy doniesienia o wzroście narcyzmu opierają się na badaniach (jeśli tak, to co jest przedmiotem tych badań), czy raczej mają charakter opinii? Rozstrzygnięcie tych kwestii jest dość istotne, koncepcje z nurtu kulturowo-społecznego zdają się bowiem odwoływać do przeróżnych teorii, zarówno psychologicznych, jak i innych, i ogólnie pozostawiają wrażenie, że nie wiadomo, jaka postać narcyzmu jest przedmiotem ich rozważań.

W nurt kulturowo-społeczny wpisuje się bardzo popularna koncepcja Lascha. Punktem kluczowym tej koncepcji jest związek narcyzmu z kulturą kapitalistyczną. Według niego każda kultura wytwarza specyficzne dla siebie metody rozstrzygania konfliktów w dzieciństwie. Sposoby przeżywania rozłąki z matką, lęki przed porzuceniem, niepokoje i urazy uwarunkowane są szerszym spektrum kulturowym, w którym mają miejsce. To sprawia, że u dziecka kształtują się specyficzne cechy osobowości, a nawet formy dewiacji psychicznych, kultura bowiem wzmacnia określone zachowania jako pożądane i ważne w danym środowisku (Lasch, 2015). Kultura kapitalistyczna, czyli kultura narcyzmu, według tego autora, nie pochwala wrażliwości oraz patrzenia na potrzeby i emocje innych. Cenione jest w niej silne ego, dążenie do sławy, sukcesu, pozycji społecznej, wrażliwość zaś i skromność uznawane są za przejawy słabości i naiwności. Potrzeba sukcesu staje się jedną z najważniejszych potrzeb ludzkich. Koncepcja Lascha w sposób oczywisty nawiązuje do myśli Fromma. Choć idee tego rodzaju były uznane za przejawy funkcjonowania świata kapitalistycznego w latach czterdziestych XX w. według dzieł Fromma, nadal są za takie uznawane w latach dziewięćdziesiątych przez Lascha. Narcyzm w wymiarze indywidualnym jest odbiciem narcyzmu w kontekście społecznym (Lasch, 2015, ss. 68-70). Narcyzm wydaje się dobrym nowym sposobem adaptacji do warunków społecznych. To sposób na radzenie sobie z napięciami i niepokojami. Osoba narcystyczna to człowiek zawieszony w próżni, niezainteresowany przyszłością ani przeszłością. Swój lęk i poczucie winy stara się ukoić na dwa sposoby: poprzez nasilenie przeżyć religijnych i duchowych oraz poprzez rozbudzanie tak zwanej „świadomości terapeutycznej” (szukanie pomocy u terapeutów). To prowadzi do chwilowego złagodzenia intensywności tego lęku, ale pogłębia poczucie własnej znikomości. Wszystko to jest też mocno powiązane z poszukiwaniem wzorców, które z kolei proponuje kultura masowa czy media. Dążenie do sukcesu staje się nadrzędnym celem, miarą człowieka jest zaś stopień, w jakim osiągnął sukces. Lasch (2015, ss. 86-87) nawiązuje też do pogoni za bogactwem, które jakoby jest znamienną właściwością naszych czasów (a dokładnie, odnosi się to do lat dziewięćdziesiątych 
ubiegłego stulecia). Media kształtują wzory, wyznaczają wartości i kierunki dążeń ludzkich. Osoba narcystyczna deprecjonuje rolę codziennych czynności i zwykłego, „banalnego”, nudnego życia. Kult bohatera, idealizacja narcystyczna wyznaczają priorytety dążeniowe (Lasch, 2015, s. 113).

Ciekawe jest nawiązanie przez Lascha do rozwoju sztuki i wskazanie, że rozwój teatru absurdu idzie w parze z typami zaburzeń, na jakie ludzie cierpieli w czasie II wojny światowej. Jednocześnie Lasch wskazuje na odmienność zaburzeń w czasach starożytnych oraz analogiczną odmienność dzieł dramatycznych Sofoklesa, Szekspira i innych (Lasch, 2015, s. 116). Sugeruje tym samym, iż poczucie pustki, dezintegracja i poczucie bezsilności jako charakterystyczne dla człowieka z okresu po II wojnie światowej znajdują odzwierciedlenie $\mathrm{w}$ teatrze absurdu, a następnie są typowe dla czasów współczesnych lat dziewięćdziesiątych. Odpowiedzialnością za taki stan rzeczy obarcza kulturę narcyzmu/kapitalizmu promującą jakoby szybkie osiąganie sukcesu, sławy itp. Klimat emocjonalny pracy Lascha bardzo przypomina ten z prac Fromma (np. O sztuce miłości, Ucieczka od wolności) w zakresie sposobu argumentowania, odwoływania się do kultury starożytnej, XIX-wiecznej i innych przeszłych czasów jako rzekomo odmiennych pod względem stosunków społecznych, emocji rodzących się w ich kontekście oraz konsekwencji w postaci zaburzeń psychicznych. Istnieje jednak różnica pomiędzy poglądami Fromma i Lascha. O ile Fromm dokonuje wnikliwej analizy, tworząc koncepcję psychoanalityczną natury ludzkiej, o tyle Lasch przywołuje raczej uproszczone i zgeneralizowane poglądy na temat tej natury, niewpisujące się ani w koncepcję psychoanalityczną, ani w egzystencjalną. Według Fromma (1997) ideą nadrzędną jest nieustanne dążenie człowieka zarówno do indywidualności, jak i afiliacji. Ten konflikt egzystencjalny jest wpisany w naturę ludzką, a manifestuje się według ujęcia Lascha pod postacią narcyzmu. Warto przywołać poglądy Fromma na ten temat (do złudzenia zbliżone są do nich poglądy Lascha), w których odnajdujemy jednak bardziej zróżnicowane formy radzenia sobie jednostki z poczuciem pustki egzystencjalnej (która nie była obca człowiekowi w latach czterdziestych XX w. ani też w jakichkolwiek czasach wcześniejszych), jak np. mechanizmy konformizmu, autorytaryzmu czy destruktywizmu (Fromm, 1997, ss. 137-179). Lasch sugeruje, że rozwiązaniem tego konfliktu jest ucieczka w narcyzm. Człowiek narcystyczny dąży do sławy, sukcesu. Nie pojmuje, że można przeżyć życie bez sławy, pieniędzy, sukcesów, zginąć w tłumie, będąc niezauważonym. Traktowanie wszystkiego, relacji rodzinnych, siebie, pracy i sportu, jako towaru prowadzi nieuchronnie do koncentracji jedynie na iluzji siebie. Osoba narcystyczna 
żąda uznania i całkowitej uległości, pragnie podporządkować sobie ludzi, nie dając nic w zamian. W ten sposób nie traci niezależności i jednocześnie unika konieczności tworzenia bliższych relacji (Lasch, 2015, ss. 180-181). Takie zachowanie/postawa/ogólna tendencja negatywnie wpływa na system rodzinny. Doprowadza do upadku autorytet rodzicielski, dewaluuje wartości pracy (nacisk na stawanie się liderem, kierownikiem i menadżerem, czyli na osoby „zwycięskie”, niedoznające porażki czy poczucia bycia nieudolnymi). Taka tendencja dewaluuje także okres starości. Inne potrzeby realizowane przez osoby narcystyczne to potrzeby materialne; gromadzenie dóbr staje się symbolem wspaniałości. Konkludując, koncepcja narcyzmu Lascha zdaje się ujmować narcyzm nieprecyzyjnie, zarówno jako postawę, cechę osobowości, jak i jako aspekt zaburzenia osobowości. Ponadto tezy sformułowane przez niego wydają się mieć charakter niepopartych żadnymi badaniami opinii popularyzatorskich.

\section{Model społeczno-poznawczy}

Podstawą tego ujęcia jest definiowanie narcyzmu jako wymiaru osobowości. Społeczno-poznawczy model narcystycznego ,ja” skoncentrowany jest na wyjaśnianiu i opisie mechanizmów intrapsychicznych osób przejawiających narcyzm jako cechę osobowości, nie zaś na kulturowych oznakach narcyzmu, wzroście czy spadku tendencji narcystycznych w kulturach/ społeczeństwach. W tym ujęciu pojawia się wiele interesujących badań i danych na temat konstrukcji psychicznej osoby narcystycznej. Na przykład Frederick Rhodewalt (2005) proponuje model narcyzmu ujęty z perspektywy społeczno-poznawczej. Według niego kluczowe elementy Ja stanowią: samowiedza, samoocena i samoregulacja. Samowiedza osób narcystycznych wydaje się niepełna; ich Ja określa się jako puste. W zakresie samooceny obserwowana jest rozbieżność między deklarowaną wysoką samooceną a poczuciem niskiej wartości. Wskazuje się, że wysoka samoocena takich osób jest wyrazem mechanizmu defensywnej autowaloryzacji. Ich samoocena jest wyjątkowo niestabilna. Aby jednak utrzymać wysoką samoocenę, osoby narcystyczne podejmują ciągle próby autoregulacji i stosują różne strategie interpersonalne, np. zabiegi autoprezentacyjne, manipulacje społeczne. Badania ujawniły, że chociaż osoby narcystyczne mają bardziej pozytywne przekonania na swój temat i większą rozbieżność między Ja realnym i idealnym, to jednak nie różnią się istotnie od osób nienarcystycznych pod względem dostępności wiedzy na temat Ja. Nie potwierdzono zatem tzw. 
modelu deficytu Ja, czyli istnienia „pustego” Ja u osób narcystycznych. Kwestia „zdezorganizowanego” Ja u tych osób także nie została potwierdzona, a organizacja pojęcia Ja nie ma charakteru uproszczonego. Z kolei pogląd wskazujący na deformację procesów związanych z Ja został zweryfikowany i wykazano, że osoby narcystyczne cechuje egotyzm atrybucyjny, który polega na wyolbrzymianiu własnych zalet.

Wiele badań potwierdza też, że osoby narcystyczne mają wysoką samoocenę. Wykazują one również dużą wrażliwość na własne porażki, jednak związki pomiędzy samooceną a narcyzmem są moderowane przez ich poziom integracji ewaluatywnej. Osoby te zatem, będąc zróżnicowanymi pod względem poziomu integracji ewaluatywnej, przejawiają bardzo zróżnicowane charakterystyki zachowania. Osoby o wysokim poziomie takiej integracji nie mają skłonności do nadmiernego uogólniania, co ma swoje konsekwencje w ocenie siebie i zachowaniu. „Skoki” samooceny dotyczą zaś głównie osób o niskiej integracji ewaluatywnej (Rhodewalt, 2005). Takie osoby częściej skłonne są też ujawniać gniew i wrogość. Ponadto wykazano duże wahania samooceny u osób narcystycznych i ich związek z aktualnymi/ostatnimi interakcjami społecznymi.

Badania nad autoregulacyjnymi mechanizmami podtrzymywania samooceny potwierdziły także, że osoby narcystyczne interpretują sukcesy jako wynik wybitnych kompetencji niezależnie od zachowania, oceniają negatywnie innych, którzy otrzymali niepochlebne oceny, w sytuacji zagrożenia przywołują tendencyjnie wspomnienia autobiograficzne, deprecjonują rolę innych (np. przyjaciół) w tej sytuacji. Ogólnie przejawiają tendencje do manipulowania informacjami w relacjach i związkach interpersonalnych w celu podtrzymania swojej samooceny (Schütz, 2005). Paradoksalnie osoby takie częściej też wykorzystują strategię samoutrudniania, w efekcie czego manipulują różnego rodzaju informacjami społecznymi w taki sposób, aby podtrzymać swoją samoocenę, poszukują zatem informacji zwrotnych niezagrażających Ja. Przejawiają takie strategie budowania tożsamości, które podtrzymują ich przesadnie pochlebną opinię na własny temat, choć takie pozytywne autozłudzenia nie mają obiektywnych podstaw. W rezultacie, ze względu na wielość i różnorodność sytuacji społecznych, ciągłych wymagań, osoba o silnych skłonnościach narcystycznych jest zobligowana do nieustannego podtrzymywania cyklu społecznego budowania tożsamości, aby potwierdzić obraz siebie (Rhodewalt, 2005).

Modelem wpisującym się w koncepcje psychologiczne jest ujęcie Roberta Raskina, które ujmuje narcyzm jako wymiar osobowościowy. Zakłada także zróżnicowanie narcyzmu. Raskin, bazując na DSM-3, stworzył 
narzędzie służące do pomiaru narcyzmu jako cechy osobowości. Przejawia się ona w czterech obszarach: domaganie się podziwu, przywódczość, próżność oraz samowystarczalność. Domaganie się podziwu manifestuje się w kontaktach interpersonalnych w postaci nasilonej potrzeby uznania. Wymiar przywództwa powiązany jest z poczuciem wpływu na innych oraz przekonaniem o posiadania umiejętności przywódczych. Natomiast wymiar próżności dotyczy podziwiania siebie oraz skupiania się na swoim wyglądzie i zachwycania się nim. Osoby osiągające wysokie wyniki na tej skali mają poczucie, że są wyjątkowe, uważają, że mają poczucie estetyki, i są zadowolone z życia. Wymiar samowystarczalności odnosi się do poczucia kompetencji. Osoby uzyskujące wysoki wynik twierdzą, że nieustannie odnoszą sukcesy i charakteryzuje je dążenie do osiągnięcia sukcesu przy jednoczesnym braku respektowania społecznych standardów regulacji (Bazińska i Drat-Ruszczak, 2000).

Koncepcje z omawianego nurtu nie tyle zajmują się tendencjami w zakresie wzrostu zachowań bądź postaw narcystycznych w krajach kapitalistycznych czy populacjach świata, ile wyjaśnianiem mechanizmów psychicznych leżących u podstaw funkcjonowania osób narcystycznych, najczęściej w rozumieniu narcyzmu jako wymiaru osobowości. Czy odnoszą się do narcyzmu jako zaburzenia? Wydaje się, że w pewnym stopniu tak, ponieważ granica pomiędzy subklinicznym i klinicznym (jako zaburzeniem osobowości) narcyzmem jest dość subtelna. Na to wskazuje również sposób definiowania narcyzmu według klasyfikacji zaburzeń, np. DSM-5 (Butcher, Hooley i Mineka, 2017).

Przytoczone powyżej koncepcje wskazują na odmienność ujmowania rozumienia narcyzmu. Koncepcje psychoanalityczne ujmują narcyzm jako właściwość osobowości lub zaburzenie (koncepcje kliniczne Freuda czy Kohuta), którego źródła sięgają zaburzonych relacji w dzieciństwie pomiędzy opiekunami i dzieckiem. Akcentują, że nieprawidłowe więzi skutkują rozwojem tego patologicznego rysu osobowości. Koncepcje społeczno-poznawcze koncentrują się na badaniu intrapsychicznych mechanizmów narcyzmu jako wymiaru osobowościowego. Natomiast koncepcje kulturowo-społeczne definiują narcyzm dość nieklarownie, tj. jako postawę, tendencję ogólnospołeczną (dotyczącą współczesnych społeczeństw), cechę osobowości, ale też patologiczny aspekt zachowania. Jedynym spośród nich sugerującym istnienie współczesnej „epidemii narcyzmu” jest nurt kulturowo-społeczny. Przypisywana społeczeństwom kapitalistycznym „epidemia narcyzmu" czy tendencja do wzrostu narcyzmu zostanie w tym miejscu odniesiona do konkretnych danych na temat rozpowszechnienia osobowości 
narcystycznej w populacjach krajów wszystkich kontynentów świata. Jeśli hipoteza Lascha ma rację bytu, to można będzie zaobserwować istotnie wysoką częstość narcystycznego zaburzenia osobowości w krajach kapitalistycznych, a także prawdopodobnie różnice pomiędzy kulturami opartymi na ideach kapitalistycznych i niekapitalistycznych.

\section{Narcystyczne zaburzenie osobowości w populacjach krajów na całym świecie}

Oprócz opisanych wcześniej ujęć narcyzmu istnieje jego kliniczna koncepcja, gdzie określany jest jako narcystyczne zaburzenie osobowości. To zaburzenie osobowości było obecne we wcześniejszych klasyfikacjach zaburzeń DSM-3 i DSM-4, a także zostało uwzględnione w najnowszej, tj. DSM-5. Według DSM-5 narcystyczne zaburzenie osobowości to „stały wzorzec zachowań i reakcji emocjonalnych związanych z poczuciem wyższości, potrzebą bycia podziwianym, brakiem zdolności do współodczuwania, rozpoczynający się u młodych dorosłych i występujący w różnych warunkach, charakteryzujący się co najmniej pięcioma z następujących: wielkościowe przekonania co do swojej wartości (np. wyolbrzymianie swoich talentów i osiągnięć), pochłonięcie wyobrażeniami o nieograniczonych sukcesach, władzy, doskonałości, pięknie, przekonanie o byciu kimś wyjątkowym i niepowtarzalnym, nadmierna potrzeba bycia podziwianym, poczucie bycia uprzywilejowanym, wykorzystywanie innych osób do osiągnięcia swoich celów, brak zdolności do współodczuwania, niechęć do rozpoznawania i identyfikowania się z potrzebami innych, częste poczucie zazdrości lub przekonanie, że inni są zazdrośni, aroganckie, wyniosłe zachowanie się lub postawa” (Butcher i in., 2017, s. 423).

Charakterystyka narcystycznego zaburzenia osobowości wskazuje na różnorodność przejawów. Co więcej, według DSM-5 istnieją także podtypy tego zaburzenia: narcyzm wielkościowy i wrażliwy (Butcher i in., 2017, s. 424). Postać wielkościowa przejawia się poczuciem własnej wielkości, agresją i dominacją. Osoba jest przekonana o szczególnych uprawnieniach, swojej wyjątkowości, mówi nieustannie o własnych osiągnięciach i domaga się upragnionego uznania. Z kolei postać wrażliwa narcyzmu nie została dokładnie opisana. Klinicyści wskazują, że takie osoby są szczególnie kruche, niestabilne emocjonalnie, przejawiają przesadną wstydliwość, są pochłonięte fantazjami na temat swoich osiągnięć i jednocześnie wstydzą się tych ambicji. Według modelu pięcioczynnikowego istnieją kluczowe odmienności 
pomiędzy tymi typami pomimo wielu podobieństw; osoby przejawiające wielkościowy typ narcyzmu wykazują niski poziom niektórych komponentów neurotyczności i wysoką ekstrawersję, osoby z podtypem wrażliwego narcyzmu opisywane są zaś jako zgorzkniałe, nietolerancyjne, okrutne, pełne napięcia, martwiące się. Różnicowanie podtypów staje jeszcze bardziej skomplikowane ze względu na to, że osoby mogą oscylować pomiędzy jednym i drugim podtypem narcyzmu (Butcher i in., 2017, s. 424). Omówiona charakterystyka wskazuje, iż obraz przejawów narcystycznego zaburzenia osobowości jest zróżnicowany i zarazem nieprecyzyjny.

Aby ustosunkować się do sugerowanej tezy o „epidemii narcyzmu”, można odnieść się do badań na temat występowania narcystycznego zaburzenia osobowości w populacjach różnych krajów. Warto zwrócić uwagę na to, że w badaniach międzykulturowych zaburzenie narcystyczne zostało oszacowane jako jedno z najrzadziej występujących na świecie, średnio w około 1,3\% przypadków (Calliess, Sieberer, Machleidt i Ziegenbein, 2008), chociaż istnieje jego zróżnicowanie w zależności od kraju i kultury. Dane na temat częstości występowania zaburzenia narcystycznego pochodzą z badań epidemiologicznych (Tyrer, Reed i Crawford, 2015), z których znakomita większość jest realizowana w Stanach Zjednoczonych. Na podstawie tych danych można wnioskować o tendencjach, a więc czy istotnie ma miejsce „epidemia narcyzmu”. Z danych wynika, że na przykład w latach dziewięćdziesiątych najczęściej występującymi były zaburzenia obsesyjno-kompulsyjne oraz bierno-agresywne, natomiast zaburzeń narcystycznych nie stwierdzono (Black, Noyes, Pfohl, Goldstein i Blum, 1993). W innych doniesieniach występowanie narcystycznego zaburzenia osobowości w Stanach Zjednoczonych szacowano na 0,4\% w latach dziewięćdziesiątych (Reich i Girolamo, 1997, s. 22). Podobnie niskie wskaźniki tego zaburzenia wykazano w badaniu grupy ponad trzystuosobowej z populacji generalnej, opublikowanym w 1998 r. (Coid, Yang, Tyrer, Roberts i Ulrich, 2006, s. 424). Z kolei w innym badaniu 229 osób z Nowego Jorku, opublikowanym w roku 1995, stwierdzono, że narcystyczne zaburzenie osobowości pojawia się u 3,9\% osób (Coid i in., 2006). W populacji studentów z Nowego Jorku w badaniu opublikowanym w 1997 r. ujawniono, iż zaburzenie narcystyczne występuje na poziomie 1,2\% (Coid i in., 2006). Inne wyniki badań opublikowane w 1998 r. wskazują, że narcystyczne zaburzenie osobowości w populacji osób z Bostonu występuje na poziomie $3,5 \%$. Natomiast badania próby z Baltimore wykazały, iż jedynie 0,03\% może przejawiać cechy narcystycznej osobowości (Samuels i in., 2002). Opublikowano też inne dane, z których wynika, że w 1997 r. 2,7\% osób 
przejawia zaburzenie narcystyczne, zaś w 2005 roku 2,3\% (Lenzenweger, Lane, Loranger i Kessler, 2007). W 2004 r. opublikowano szeroko zakrojone badania epidemiologiczne obejmujące próbę ponad 43 tys. Amerykanów, a wykorzystano w nim narzędzie oparte na DSM-4. Wykazano, że najczęściej występujące jest zaburzenie obsesyjno-kompulsyjne (Grant i in., 2004). Oznacza to, iż ogólnie częstość występowania zaburzenia narcystycznego osobowości w populacji Stanów Zjednoczonych jest niska. Choć wyniki badań są bardzo zróżnicowane w zależności od roku badania i rodzaju próby, a także zastosowanej techniki, to dominuje niska częstość (przy ogólnej częstości występowania zaburzeń osobowości ok. 14\%), w granicach jednego lub poniżej dwu procent. Takie wyniki nie oznaczają bynajmniej „epidemii narcyzmu” sugerowanej przez Lascha.

Kolejne kraje Ameryki Północnej to Meksyk i Kanada. Dane dotyczące występowania zaburzeń osobowości w Meksyku wskazują na ogólnie niższe wskaźniki zaburzeń niż w Stanach Zjednoczonych. W meksykańskim ogólnonarodowym badaniu występowania zaburzeń obejmującym bardzo dużą próbę osób badanych $(\mathrm{n}=2,362)$ wykazano, że ogólny wskaźnik częstości zaburzeń osobowości wynosi 6,1\%, najczęściej występują zaburzenia z wiązki A (4,6\%), z wiązki C (2,4\%) oraz najrzadziej z wiązki B (1,6\%) (Benjet, Borges i Medina-Mora, 2008). Należy przypomnieć, iż zaburzenie narcystyczne należy do wiązki B według DSM-4 i DSM-5, a częstość występowania tej grupy zaburzeń została oszacowana jako niska (1,6\%). Uzyskane dane wskazują zatem, że w populacji meksykańskiej zaburzenie narcystyczne występuje stosunkowo rzadko. Z kolei odnośnie do Kanady, ze względu na brak danych na temat narcystycznego zaburzenia, trudno odnieść się do dyskutowanej kwestii. Istnieją jedynie ogólne dane na temat występowania zaburzeń osobowości, wskazuje się, że częstość występowania zaburzeń osobowości w Kanadzie jest zbliżona do Stanów Zjednoczonych, wynosi od jednego do dziesięciu procent (Stewart, Lips, Lakaski i Upshall, 2002).

W odniesieniu do Ameryki Południowej dane są również skromne. Ogólna częstość występowania zaburzeń osobowości w Kolumbii jest zbliżona do tej w Meksyku, natomiast brakuje danych odnośnie do zaburzenia narcystycznego (Huang i in., 2006). Z kolei w Brazylii badania wykazały, że wśród osób niebędących pacjentami i bezdomnymi najczęściej występują zaburzenia borderline i obsesyjno-kompulsyjne, zaburzenie narcystyczne jest zaś trzecie pod względem częstości (średnia wynosi 2,19), choć wskaźnik ten jest dość niski (Bartholomeu i in., 2015). Należy jednak podkreślić, że omawiane badanie obejmuje dość małą i niereprezentatywną próbę. Nie ma zatem możliwości odniesienia tych wyników do tezy dyskutowanej 
w niniejszym artykule. Co istotne, badacze podkreślają, iż osoby pochodzące z Ameryki Południowej mogą być mylnie diagnozowane w szczególności w zakresie zaburzenia borderline, histrionicznego i narcystycznego (Calliess i in., 2008). Wynika to z faktu, że typowe cechy tych zaburzeń, jak nasilona emocjonalność, somatyzacja, tendencja do dramatyzowania i uwodzicielskie zachowania, charakterystyczne są także dla ekspresji emocji u mieszkańców tych rejonów. Podobnie w kulturach Europy Południowej istnieją inne normy społeczne dotyczące ekspresji emocji, gdzie cechy ożywionej i nadmiarowej ekspresji mogą być mylnie diagnozowane jako przejawy zaburzeń osobowości. Dotyczy to także diagnozy zaburzenia narcystycznego w tych kulturach i krajach, które w pewien sposób może być powiązane z nadmiarową ekspresją emocjonalną. Osoba o cechach narcystycznych, skoncentrowana na sobie, może taką nadmiarową ekspresję przejawiać.

Częstość występowania zaburzeń osobowości w Europie jest bardziej zbliżona do częstości w Stanach Zjednoczonych niż w Ameryce Południowej. Wskaźniki ogólnego występowania zaburzeń osobowości niekiedy podawane są dość niskie, np. dla zachodniej Europy ogólny wskaźnik wynosi 2,4\% (Huang i in., 2006). W innych analizach na podstawie badań z wykorzystaniem narzędzia opierającego się na ICD-10 ustalono, że narcystyczne zaburzenie osobowości nie występuje w populacji Londynu (Loranger, Janca i Sartorius, 1997). Najczęściej występującymi są zaburzenia z wiązki C, w tym obsesyjno-kompulsyjne, jednak nie ma danych na temat zaburzenia narcystycznego (Coid i in., 2006).

Dane na temat częstości występowania zaburzeń osobowości w Norwegii w 2001 r. wskazują, że w populacji Oslo zaburzenia osobowości ogólnie występują na poziomie 13,4\%. Najczęściej występującym zaburzeniem jest zaburzenie unikające, zaburzenie narcystyczne występuje zaś na poziomie 0,8\% (Torgersen, Kringlen i Cramer, 2001). We wcześniejszym badaniu występowanie narcystycznego zaburzenia w tym kraju oszacowano na poziomie 2,1\% (Loranger i in., 1997). W innym skandynawskim kraju, Szwecji, ogólna częstość występowania zaburzeń osobowości jest podobnie wysoka jak w Norwegii, szacuje się ją na poziomie 11\%. Za najczęściej występujące zaburzenie w populacji Szwecji uznaje się obsesyjno-kompulsyjne, narcystyczne występuje zaś na poziomie 2,9\% (Ekselius, Tillfors, Furmark i Fredrikson, 2001). W kolejnym europejskim wysoko rozwiniętym kraju, Austrii, zaburzenie narcystyczne oszacowano na 2,0\% (Loranger i in., 1997). Z kolei w Niemczech za najczęściej występujące zaburzenie osobowości uznaje się obsesyjno-kompulsyjne, podobnie jak w wielu innych 
krajach Europy, natomiast zaburzenia narcystycznego nie stwierdzono (Maier, Lichtermann, Klingler, Heun i Hallmeyer, 1992). Z kolei w innych badaniach wykazano występowanie narcystycznego zaburzenia osobowości w Niemczech na poziomie 3,5\% (Loranger i in., 1997).

Dane na temat występowania zaburzeń osobowości/cech zaburzeń osobowości w Polsce pochodzą z dwu źródeł. Pierwszym są badania nieklinicznej próby elektroniczną wersją Kwestionariusza Style Życia 05/F zrealizowane przez zespół Ewy Trzebińskiej. Z badań tych wynika, że w Polsce najczęściej występują zaburzenia osobowości: schizotypowe (8,6\%), paranoiczne (6,1\%) oraz histrioniczne (6,1\%) (Trzebińska i Gabińska, 2014). Drugie źródło to badania z zastosowaniem Ustrukturalizowanego Wywiadu Klinicznego (SCID-II) opartego na DSM-4 zrealizowane na dużej próbie ( $\mathrm{n}=2400)$ wyselekcjonowanej z populacji generalnej osób w wieku od 18 do 65 lat. W tych badaniach ustalono nie częstość występowania zaburzeń osobowości, lecz częstość występowania cech zaburzeń osobowości. Wykazano, że najczęściej w populacji polskiej występują cechy zaburzenia osobowości obsesyjno-kompulsyjnego (9,6\%), narcystycznego (7\%) oraz borderline (7\%) (Gawda i Czubak, 2017). Dane z 2017 r. w odniesieniu do częstości nasilenia cech zaburzenia obsesyjno-kompulsyjnego są spójne z danymi w Stanach Zjednoczonych czy w innych krajach Europy Zachodniej. Są natomiast nieco odmienne w odniesieniu do cech narcystycznego zaburzenia osobowości. Cechy tego ostatniego okazały się często występujące w populacji polskiej, co nie jest jednak wskazywane w badaniach w innych krajach Europy. Polska jako jedyny przedstawiciel krajów kapitalistycznych mógłby stanowić potwierdzenie dla idei Lascha. Co ciekawe, w innym badaniu w odniesieniu do kwestii narcyzmu jako wymiaru osobowości w populacji polskiej stwierdzono istnienie wyższego poziomu ukrytego narcyzmu w porównaniu do osób z Holandii (Zondag, Van Halen i Wojtkowiak, 2009).

Dane na temat innych krajów europejskich, np. populacji tureckiej, są jednostkowe. Badanie populacji generalnej Turcji z zastosowaniem technik opartych na DSM-4 i ICD-10 (DIP-Q) ukazało dość nieoczekiwane rezultaty: co najmniej 20\% populacji przejawia zaburzenia osobowości. Wskaźnik ten wydaje się największy spośród wszystkich krajów badanych na całym świecie. Spośród najczęściej występujących w Turcji autorzy wskazują zaburzenie schizotypowe i obsesyjno-kompulsyjne. O ile częstość zaburzenia obsesyjno-kompulsyjnego wydaje się spójna z danymi dotyczącymi społeczeństw zachodnich, o tyle zaburzenie schizotypowe może w jakiś sposób odzwierciedlać cechy charakterystyczne populacji tureckiej 
(Dereboy, Güzel, Dereboy, Okyay i Eskin, 2013). Nie ma jednak wskazań, że w populacji tureckiej występuje nasilenie zaburzenia narcystycznego.

Podobnie jak w Europie, badania populacji azjatyckich wskazują, że zaburzenie narcystyczne osobowości występuje tam dość rzadko, np. w populacji Japonii częstość tego zaburzenia szacuje się na poziomie 1,8\% (Loranger i in., 1997), a Japonia, co należy podkreślić, jest krajem wysoko rozwiniętym i kapitalistycznym i dane na jej temat mogłyby stanowić istotny argument w dyskusji tzw. kwestii „epidemii narcyzmu”. W Japonii najbardziej cenionymi wartościami są: wysoki perfekcjonizm, silne dążenie do precyzji, porządku i dokładności. Mogą one oddziaływać na funkcjonowanie jednostki w taki sposób, że sprzyjają ukształtowaniu się cech obsesyjno-kompulsyjnych, co skutkuje wysokim natężeniem tych cech w populacji Japonii, nie zaś cech narcystycznych. Dodatkowo wymiar indywidualizm-kolektywizm może mieć tutaj znaczenie wyjaśniające. Kultura Japonii to kultura kolektywistyczna, jak większość krajów Azji, stąd nie ma sprzyjających warunków dla rozwoju i ukształtowania cech narcystycznego zaburzenia osobowości (Calliess i in., 2008).

Ogólnie w krajach Azji częstość zaburzeń osobowości jest niższa niż w krajach Ameryki Północnej czy zachodniej Europy (Huang i in., 2006). Niektóre zaburzenia nie występują w ogóle, np. w Chińskiej Klasyfikacji Zaburzeń nie pojawia się unikające zaburzenie osobowości ani też zależne czy borderline (Calliess i in., 2008). Brak tych zaburzeń najprawdopodobniej wiąże się z silnym wpływem filozofii konfucjańskiej na mentalność i zachowanie społeczności Chin. Relacje interpersonalne są oparte na wartościach wynikających z tej filozofii. A wartościami tymi są dobre wychowanie, prawość i wybaczanie. Skłaniają do rozwoju postawy uległości i zależności, stąd nie są one traktowane jako przejaw dysfunkcji, ale wręcz przeciwnie, jako normy.

Dane na temat występowania zaburzeń osobowości w Afryce są jednostkowe. Ogólny wskaźnik w RPA wynosi 6,5\%, w Nigerii 3,5\% (Huang i in., 2009). Inne dane wskazują na podobny ogólny wskaźnik zaburzeń w RPA, na poziomie $6,8 \%$, nie ma jednak danych na temat narcystycznego zaburzenia osobowości (Loranger i in., 1997). Z kolei populacja Australii została przebadana pod kątem występowania zaburzeń osobowości i oszacowano ogólny wskaźnik na poziomie 6,5\% (Jackson i Burgess, 2000). Stwierdzono tendencję wzrostową w zakresie występowania zaburzeń osobowości w populacji australijskiej, za najczęściej występujące uznano zaś zaburzenie obsesyjno-kompulsyjne (10,3\%) oraz unikające (9,3\%), narcystycznego zaburzenia jednak nie stwierdzono (Jackson i Burgess, 2000). W badaniu 
kobiet australijskich wykazano, że zaburzenie narcystyczne należy do rzadko występujących (Quirk i in., 2017).

Ogólnie zatem, pomimo rejestrowanej tendencji do wzrostu częstości zaburzeń osobowości w krajach wysoko rozwiniętych, pewnych odmienności w zakresie dominujących cech zaburzeń pomiędzy krajami Azji, Afryki, Australii, Ameryki Północnej, Ameryki Południowej i Europy, częstość występowania narcystycznego zaburzenia osobowości jest dość niska.

\section{Podsumowanie: czasy raczej „obsesyjno-kompulsyjne" niż narcystyczne}

Istnieją ogólne poglądy w badaniach międzykulturowych, że wymiary indywidualizm vs. kolektywizm, idiocentryzm vs. allocentryzm są powiązane z częstością występowania zaburzeń osobowości (Calliess i in., 2008). Zakłada się, iż kultury nastawione na promowanie jednostki, jej niezależności i rozwoju nie sprzyjają rozwojowi relacji opartych na bliskości i intymności (Gawda i Bochyńska, 2016). Za takie kultury uznaje się kraje wysoko rozwinięte Europy Zachodniej i Stanów Zjednoczonych. Zgodnie z tezą Lascha powinno w nich występować szczególne nasilenie narcyzmu czy zaburzenia narcystycznego osobowości. Nie wykazano jednak takiej tendencji; w tych krajach dominuje obsesyjno-kompulsyjne zaburzenie osobowości, nie zaś narcystyczne. Z kolei kultury kolektywistyczne, w których promowane jest dobro wspólne, pewna zależność od tradycji, w mniejszym stopniu stawiają na rozwój jednostki niż grup społecznych, powinny zatem charakteryzować się odmiennymi wzorcami występowania zaburzeń. Wykazano wszakże, że w istocie jedynie częściowo tak jest. Wzorce kulturowe przenikają się bowiem wzajemnie i ogromne zróżnicowanie czynników oddziałujących na kształtowanie osobowości człowieka powoduje trudności w ustaleniu, po pierwsze, jaki charakter (tzn. np. czy kolektywistyczny, czy indywidualistyczny) ma dana kultura, po drugie, jakie właściwości osobowości są zdeterminowane czynnikami kulturowymi, a jakie innymi. Generalnie zaprezentowane dane nie wskazują w żaden sposób na istnienie nasilonych tendencji w zakresie narcyzmu w krajach kapitalistycznych, wysoko rozwiniętych (z wyjątkiem Polski). Być może tendencje, o których mowa w koncepcjach kulturowo-społecznych odnośnie do narcyzmu, nie dotyczą zaburzeń osobowości, ale jakichś postaw/zachowań społecznych, które jednak nie są definiowane jako cechy narcystycznego zaburzenia osobowości. Kluczowy problem w rozstrzygnięciu tej kwestii wydaje się mieć źródło, 
w dużym stopniu, w samej definicji pojęcia „narcyzm” wykorzystywanej przez modele kulturowo-społeczne. Nadużywanie tego pojęcia w bliżej nieokreślonym znaczeniu jest, jak się zdaje, znamienne dla „naszych czasów”. Skądinąd dane epidemiologiczne na temat zaburzeń osobowości wskazują nie tyle na narcystyczne tendencje społeczeństw kapitalistycznych/wysoko rozwiniętych, co zdecydowanie na ich rys „obsesyjno-kompulsyjny”.

\section{Literatura}

Bartholomeu, D., Montiel, J. M., Fiamenghi, G. A., Carvalho, L. F., Orsini, M. R., Ribeiro, C. R. (2015). Personality disorders in Brazilian homeless compared with nonpsychiatric and psychiatric patients. Psychologia, 6, 1022-1028.

Bazińska, R., Drat-Ruszczak, K. (2000). Struktura narcyzmu w polskiej adaptacji kwestionariusza NPI Raskina i Halla. Czasopismo Psychologiczne, 6, 171-187.

Benjet, C., Borges, G., Medina-Mora, M. E. (2008). DSM-IV personality disorders in Mexico: results from a general population survey. Review of Brasilian Psychiatry, 30 (3), 227-234.

Black, D. W., Noyes, R., Pfohl, B., Goldstein, R. B., Blum, N. (1993). Personality disorder in obsessive-compulsive volunteers, well comparison subjects, and their first degree relatives. American Journal of Psychiatry, 150, 1226-1232.

Butcher, J., Hooley, J., Mineka S. (2017). Psychologia zaburzeń DSM-V. Gdańsk: Gdańskie Wydawnictwo Psychologiczne.

Calliess, I. T., Sieberer, M., Machleidt, W., Ziegenbein, M. (2008). Personality disorders in a cross-cultural perspective: impact of culture and migration on diagnosis and etiological aspects. Current Psychiatry Reviews, 4, 39-47.

Coid, J., Yang, M., Tyrer, P., Roberts, A., Ulrich, S. (2006). Prevalence and correlates of personality disorder among adults aged 16 to 74 in Great Britain. British Journal of Psychiatry, 188, 423-431.

Czarna, A. (2008). Narcyzm - z perspektywy 120 lat istnienia pojęcia. W: P. Winiecki, R. Grzybek (red.), Wybrane problemy współczesnej psychologii (ss. 95-117). Wrocław: ATUT.

Dereboy, C., Güzel, H. S., Dereboy, F., Okyay, P., Eskin, M. (2013). Personality disorders in a community sample in Turkey: Prevalence, associated risk factors, temperament and character dimensions. International Journal of Social Psychiatry, 60 (2), 139-147.

Ekselius, L., Tillfors, M., Furmark, T., Fredrikson, M. (2001). Personality disorders in the general population: DSM-IV and ICD-10 defined prevalence as related to sociodemographic profile. Personality \& Individual Differences, 30, 311-320.

Fromm, E. (1997). Ucieczka od wolności, przeł. A. Ziemilski. Warszawa: Czytelnik.

Gawda, B. (2011). Skrypty miłości, nienawiści i lęku u osób antyspołecznych. Warszawa: Difin.

Gawda, B., Bochyńska, K. (2016). Love in the multicultural world. Studia Społeczne, 2, 5-13.

Gawda, B., Czubak, K. (2017). Prevalence of personality disorders in a general population among men and women. Psychological Reports, 120 (3), 503-519.

Gościniak, J., Mocek, M. (2008). Narcyzm i patologia narcystyczna w ujęciu psychologii Self Heinza Kohuta. Roczniki Psychologiczne, 9 (2), 7-26. 
Grant, B. F., Hasin, D. S., Stinson, F. S., Dawson, D. A., Chou, S. P., Ruan, W. J., Pickering, R. P. (2004). Prevalence, correlates, and disability of personality disorders in the United States: results from the national epidemiologic survey on alcohol and related conditions. Journal of Clinical Psychiatry, 65 (7), 948-958.

Huang, B., Grant, B. F., Dawson, D. A., Stinson, F. S., Chou, S. P., Saha, T. D., Goldstein, R. B., Smith, S. M., Ruan, W. J., Pickering, R. P. (2006). Race-ethnicity and the prevalence and co-occurrence of Diagnostic and Statistical Manual of Mental Disorders, Fourth Edition, alcohol and drug use disorders and Axis I and II disorders: United States, 2001 to 2002. Comprehensive Psychiatry, 47 (4), 252-257.

Huang, Y., Kotov, R., de Girolamo, G., Preti, A., Angermeyer, M., Benjet, C., Demyttenaere, K., de Graaf, R., Gureje.,O., Karam, A. N., Lee, S., Lépine, J. P., Matschinger, H., Posada-Villa, J., Suliman, S., Vilagut, G., Kessler, R. C. (2009). DSM-IV personality disorders in the WHO World Mental Health Surveys. The British Journal of Psychiatry, 195, 46-53.

Jackson, H. J., Burgess, P. M. (2000). Personality disorders in the community: a report from the Australian National Survey of Mental Health and Wellbeing. Social Psychiatry and Psychiatric Epidemiology, 35, 531-538.

Lasch, C. (2015). Kultura narcyzmu. Amerykańskie życie w czasach malejq̨cych oczekiwań, przeł. G. Ptaszek, A. Skrzypek. Warszawa: Wydawnictwo Akademickie Sedno.

Lenzenweger, M. F., Lane, M. C., Loranger, A. W., Kessler, R. C. (2007). DSM-IV personality disorders in the National Comorbidity Survey Replication. Biological Psychiatry, 62, 553-564.

Loranger, A. W., Janca, A., Sartorius, N. (red.) (1997). The ICD-10 international personality disorder examination (IPDE). Cambridge-New York: Cambridge University Press.

Lowen, A. (2013). Narcyzm. Zaprzeczenie prawdziwemu ,ja”. Koszalin: Polimer.

Maier, W., Lichtermann, D., Klingler, T., Heun, R., Hallmeyer, J. (1992). Prevalence of personality disorders (DSM-3-R) in the community. Journal of Personality Disorders, 6, 187-196.

Moran, P., Rooney, K., Tyrer, P., Coid, J. (2014). Personality disorders. W: S. McManus, P. Bebbington, R. Jenkins, T. Brugha (red.), Mental health and wellbeing in England: Adult Psychiatric Morbidity Survey (ss. 1-15). Leeds: NHS Digital.

Olchanowski, T., Sieradzan, J. (2011). Wprowadzenie do problematyki narcyzmu. Od klasycznych koncepcji narcyzmu do narcyzmu kultury zachodniej. W: J. Sieradzan (red.), Narcyzm (ss. 7-71). Białystok: Uniwersytet w Białymstoku.

Pospiszyl, K. (1995). Narcyzm. Drogi i bezdroża miłości własnej. Warszawa: WSiP.

Pulver, S. E. (1970). Narcissism. The term and the concept. Journal of the American Psychoanalytic Association, 18, 319.

Quirk, S. E., Berk, M., Pasco, J. A., Brennan-Olsen, S. L., Chanen, A. M., Koivumaa-Honkanen, H., Burke, L. M., Jackson, H. J., Hulbert, C., A. Olsson, C., Moran, P., Stuart, A. L., Williams, L. J. (2017). The prevalence, age distribution and comorbidity of personality disorders in Australian women. Australian \& New Zealand Journal of Psychiatry, 51, 141-150.

Reich, J. H., de Girolamo, G. (1997). Epidemiology of DSM-111 personality disorders in the community. W: A. W. Loranger, A. Janca, N. Sartorius (red.), Assessment and diagnosis of personality disorders: the ICD-10 International Personality Disorder Examination (IPDE) (ss. 18-43). Cambridge: Cambridge University Press. 
Rhodewalt, F. (2005). Umysł społeczny narcyza - poznawcze i motywacyjne aspekty budowania tożsamości poprzez relacje interpersonalne. W: J. P. Forgas, K. D. Williams, L. Wheeler (red.), Umysł społeczny. Poznawcze i motywacyjne aspekty zachowań interpersonalnych (ss. 188-208), przeł. A. Nowak. Gdańsk: Gdańskie Wydawnictwo Psychologiczne.

Samuels, J., Eaton, W. W., Bienvenu, O. J. III, Brown, C. H., Costa, P. T. Jr, Nestadt, G. (2002). Prevalence and correlates of personality disorders in a community sample. British Journal of Psychiatry, 180, 536-542.

Schütz, A. (2005). Samoocena a strategie interpersonalne. W: J. P. Forgas, K. D. Williams, L. Wheeler (red.), Umysł społeczny. Poznawcze i motywacyjne aspekty zachowań interpersonalnych (ss. 169-183), przeł. A. Nowak. Gdańsk: Gdańskie Wydawnictwo Psychologiczne.

Stewart, P., Lips, T., Lakaski, C., Upshall, P. (2002). A report on mental illnesses in Canada. Ottawa: Canadian Mental Health Association.

Symington, N. (2013). Narcyzm. Nowa teoria, przeł. B. Boryczko-Pater, L. Kalita. Gdańsk: IMAGO.

Szpunar, M. (2014). Od narcyzmu jednostki do kultury narcyzmu. Kultura - Media - Teologia, 18, 106-116.

Szpunar, M. (2016). Kultura cyfrowego narcyzmu. Kraków: Wydawnictwo AGH.

Torgersen, S., Kringlen, E., Cramer V. (2001). The prevalence of personality disorders in a community sample. Archives of General Psychiatry, 58, 590-596.

Trzebińska, E., Gabińska, A. (2014). Features of emotional experiences in individuals with personality disorders. Polish Psychological Bulletin, 45, 147-155.

Twenge, J. M., Campbell, W. K. (2009). The narcissism epidemic: living in the age of entitlement. New York: Free Press.

Tyrer, P., Reed, G. M., Crawford, M. J. (2015). Classification, assessment, prevalence, and effect of personality disorder. Lancet, 385 (9969), 717-726.

Zondag, H. J., Van Halen, C., Wojtkowiak, J. (2009). Overt and covert narcissism in Poland and the Netherland. Psychological Reports, 104 (3), 833-843. 